\title{
Documenting Refugee Stories: Resettlement and Integration Challenges of East African Refugees
}

\author{
Nimo Bokore, MSW, PhD \\ Carleton University School of Social Work
}

509 Dunton Tower, 1125 Colonel By Drive, Ottawa, Ontario, Canada K1S 5B6

Received: January 2, 2016 Accepted: April 16, 2016 Published: April 19, 2016

doi:10.5296/ijsw.v3i1.8814 URL: http://dx.doi.org/10.5296/ijsw.v3i1.8814

\begin{abstract}
Recently we have witnessed forced displacement and migration on a globalized scale and the human suffering that this creates. Since early 2014, events have escalated in Syria and other Middle Eastern countries as religious-based interest groups such as ISIS push to make territorial gains. One cannot escape media reports documenting the devastating impact this has as refugees try to reach safety, whether by crossing the Mediterranean Sea or European borders.

In this article, I present my personal experience of refugee life as a survivor of war and multiple forced migrations and as a professional service provider to immigrants and refugees who make Canada their new home. In many ways, my story is the story of other refugees who also encounter issues of race, religion and geopolitical locations as they migrate and resettle in a new country.
\end{abstract}

Keywords: Refugee stories, Resettlement, Integration and Challenges

\section{Bridging Over Barriers: Refugee Resettlement and Integration Question}

Throughout my educational training in social work studies, refugees and resettlement issues have been a burning question in regards to integration becoming a particular interest of mine. In the past decade, I focused on exploring the functions of exclusion and inclusion criteria that are silently used against non-European refugees based on geopolitics and western economic interests of the time. In my journey through undergraduate and graduate programs in social work I also learned about western immigration and resettlement history. This tells us, how eugenics was used in the late nineteenth and early twentieth century's development of sterilization policies, the prohibition of miscegenation, and the restriction on immigration. It is historical information available in the minutes of the meeting the Committee on Immigration of the Eugenics Research Association held at the Harvard Club, New York City, at 11.00 a.m. 
on February 25, 1920 (Eugenics Research Association, 1920). It is still being used silently to determine the selection criteria used to resettle certain refugee and immigrant groups (Note 1) (Folson, 2004).) In past decades, while practicing as a clinical social worker, I have continued to think about the silent presence of eugenics and how refugees' past and present trauma impact individuals, their families and communities as they struggle to overcome the barriers silently imposed on them.

I began searching for new ways of helping individuals and members of these communities as they faced these resettlement barriers where their past historical trauma collide with the present and transcending to the future as a form of transference. In particular, I am concerned about my own community, the Somali-Canadians who arrived over two decades ago with a traumatic history that is still present in their lives.

My challenge was coming up with acceptable methods of social work intervention that will be well received and used by both service providers and services users; a program that will bring together people who have been impacted by repeated trauma, fear and internal self-isolation, brought on by the need for resistance against the unknown but fearful intrusions and exclusions. For this community, external isolations are brought on by the exclusionist and systemic barriers based on race, religion and the media's interpretation of the level of threat that religious, racial or political groups may have on the larger society.

In an attempt to interrogate these multiple barriers, I return to my professional roots as a social worker and my community knowledge of what will work for Somali-Canadians when it comes to service accessibility and use. When I think about where to start, it always comes back to understanding how people got to where they are today. I believe this is an important starting point for social work intervention, which begins by understanding the world of the particular community they are serving. This brings me back to the importance of using familiar cultural practices of communication including sharing resources and information. For Somalis, this is storytelling for emotional healing, a practice that developed over the course of centuries and is still being used for knowledge sharing and skills training (Andrzejewski \& Lewis, 1964; Samatar, 1982).

For communities such as Somalis who are impacted by colonial division, forced migration, internal tribal hate and recent religious practice changes, stories are what will unite them. Stories ease the tension, fear, mistrust and establish a common goal, which in their case is overcoming persistent poverty and a life filled with toxic stress. Throughout my study and practice, I have begun to see the benefits of using non-threatening, non-labeling or stigmatizing talk, which neuroscience knowledge provides (Cozolino, 2010; Siegel, 2007, 2011). This knowledge sheds light on the biological impacts of existing issues and also provides hope for healing through community dialogue and environmental change.

Story telling based on this knowledge, not only can help us as social workers understand trauma, but also explain existing sources of trauma and their impact on people's general wellbeing. The impact of past and present trauma is something that is understudied but important to communities like mine. Even though I am suggesting that cultural practices be integrated with acceptable methods of social work intervention I also now found the benefits 
of integrating a neurobiological analysis of trauma that comes from social neuroscience (Cozolino, 2010; Siegel, 2007, 2011; Matto et al., 2014; van der Kolk, 2014). I am aware of the limitation of using the full scope of neuroscience such as the use of laboratory tests (fMRI) in social work intervention. In neuroscience: the use of this test has proven to be a valuable tool in monitoring talk therapy outcomes, but they can also be seen by some as intrusive for social work intervention (Buchheim et al., 2013).

\section{My Story of Displacement and Migration}

My professional view on refugee resettlement and searching for a new ways of knowing comes from my own personal story and the experience of multiple forced migrations and resettlement barriers. My history is filled with narratives of colonization, liberation, deportation, and displacement in a region that has been in the news for many decades. My own story of displacement begins with the overthrow of Ethiopian Emperor Haile Selassie by the military dictator Mengistu Haile Mariam in 1974. When he took power, he began to imprison or execute those who opposed him or were accused of the act and treason. Unfortunately I was one of the accused and the lucky ones to escape death but still live with the impact of torture and time spent in prison. But the roots of my story go back further. My father was a respected religious and academic leader in the former British Somaliland. Before the independence of Somaliland in 1960, he was also one the leaders like other Somali leaders who dreamed of unifying a nation under one flag, not based on tribal identity but on Somali ethnicity. Until 1977-78, when the Somali government invaded Ethiopia, that idea was prominent in the minds of the majority of Somalis in the Ethiopian region too. The majority of the Somali ethnic groups at the time believed in freedom and one Somali nation or Soomaaliweyn (Greater Somalia- this is a concept that no longer exists). Due to a suspicion about the level of his activities in that idea, he was deported to Ethiopia in the late 1950s by the British colonial rule. Suspected Somali leaders like him were often deported to tribally designated land or regions. It was a practiced informed by all colonials including the Italians, the French and the British. For my father, a deportation between Ethiopia and British Somali-Land happened due to his particular sub-clan who reside in both Ethiopia and Somaliland. As a result Ethiopia was the preferred place for deportation when the British did not wane him in their territory. This created for him and his family a forced displacement to and from Ethiopia and Somali-Land. My family's story is the story of many displaced Somalis in Canada and around the world who experienced past colonial rules, oppression and trauma. It is this story rooted in colonial history to which I often turn to in order to understand or make sense of current Somali-Canadian issues. I believe as a community member it is important to understand the past while dreaming/imagining the future. In social work practice, this is an important step for prioritizing the needs of the communities we are trying to serve. This start gives us a knowledge we can use to avoid misunderstanding and disservice. It also reminds us of the Judeo-Christian history of helping that shapes our profession but that does not fully function in our current community (Bokore, 2009, 2012). In practice we often make a modernist mistake of assuming there is only one way to deal with social issues impacting certain groups (Mullaly, 1997, 2001) without looking for other possibilities. This generalized assumption hides the individual and community differences 
based on their past colonial history, migration status and current community issues (Galabuzi, 2001; Folson, 2004). For Somalis, one of the main issues is always rooted in their colonial history (Bulhan, 2008).

\section{The Outcome of the $\mathbf{1 8 8 4}$ African Partition for Somalis}

Somalia's fate was sealed when the British, under the banner of the Imperial British East Africa Company, arrived on Somalia's northeast coast opposite Aden (Burton, 1856; Bulhan, 200; Samater, 1991). The British had already labelled Somalis as expansionist and troublemakers who had pushed out other clans in the past (Samatar, 1991). To control the people they already labeled as trouble makers, they used subtle but brutal actions against them (Bulhan, 2008). Furthermore, the British colonials never missed a step against Somalis, whom they saw as Muslim aggressors against Christianity in that region. As a result, collaborating with other colonials, they controlled the movements of Somalis in that region by limiting their pastoralist activities (searching for grazing lands and water) at times to certain overcrowded territories, which was disastrous for this pastoralist ethnic group (Lewis, 1961, 1988, 2002; Cassanelli, 1982; Samatar, 1991, 1994; Bulhan, 2008). This colonial action often created food shortages and famine for Somalis who are still traumatized by those memories, creating a need for individualistic survival methods and lack current political solutions (Lewis, 1961, 1988, 2002; Cassanelli, 1982; Bulhan, 2008). It is a human tragedy and a traumatic part of Somali history that will be remembered through generations.

This colonial history shows the impact it had on Somalis who are still paying by the destruction of their country and lack of a stable government. Urbanized Somalis, like father's family, also experienced deportation and segregation without the opportunity to develop their regions in the areas of education and health care. For example, development in eastern Ethiopia or Killil (region) began only recently during Meles Zenawi's government. This type of colonial oppression, political maneuvering and economic contestation had significant effects not only on Somali pastoralists but urbanized Somalis like my father who lived in cities within the newly defined boarders.

Somali historians, Said Samater (1982) and Ahmed Samatar (1991) claims that exile and forced migration for Somalis began over a century ago during the 1884 African partition at the Berlin Conference (Cassanelli, 1982, p. 183). At this conference, the entire Horn of Africa was divided between colonial powers and geopolitical borders became the lines of demarcation. This arbitrary division separated families and forever changed the Somali culture and way of life. Somali poet Faarah Nuur (1880-1930) explained the impact of the 1884 African partition on Somalis:

The British, the Ethiopian, and the Italians are squabbling,

The country is snatched and divided by whosoever is stronger,

The country is sold piece by piece without our knowledge,

And for me all this is the Teeth of the Last Days! (quoted in Samatar, 1982, p. 92)

As alluded to in this poem, a number of treaties were signed between Ethiopia and European colonial powers, which allowed them to consolidate Somali lands as their own territories and 
initiated the dislocation and continuous suffering of Somalis to this day (Bulhan, 2008, pp. 27-29; Cassanelli, 1982, p. 30).

I grew up hearing stories about the Somali struggle for freedom, but also the collective punishment they endured. Killings and starvation through restriction of movement, deportation to one of the five regions, separation from their families and emotional trauma have all been part of Somali history in the past century. For example, the histories of Eastern Ethiopian Somalis tell us about their long struggle for freedom or equality with other Ethiopians. One of those struggles that initiated or left another damaging history for Somalis was the 20-year war that began in 1899. This war known as the Dervish army invasion was led by Sayid Mohammed Abdulle Hassan who invaded Ethiopia but was defeated by Ethiopians with the help of the British (Samater, 1982). In my view this changed how Somalis were seen in the region including Ethiopians and other neighbouring countries. Somalis who were labelled by the European explorers as invaders and trouble makers gained another added label by neighbouring countries as "shiftas," or terrorists and were never treated fairly after that by the international communities (Samatar, 1991; Bulhan, 2008).

\section{Living with the Outcomes of Partition, Multiple Dislocations and Labelling}

These mistreatments of my ethnic group become part of my life as I mentioned earlier starting with my birth which coincided with the time when the independence movement of Somaliland was getting stronger. The Ethiopian government, fearing that the movement would spill over into Eastern Ethiopia, deported leaders, including my father, back to Somaliland, forcing him to leave his wife and child-myself-behind. My father's deportation back to Somaliland meant that my mother, whom he had married when he arrived in Ethiopia, and I were left to fend for ourselves. This forcible separation from my father was my first experience of displacement. As a child, going back and forth to visit my father, leaving my mother in Ethiopia, I questioned where I belonged. I was seen by Ethiopians as Somali and by Somalis, due to my birth, as Ethiopian. This question stayed with me when I was later imprisoned and tortured because of my ethnicity. I saw myself then, even as I do today, as a product of colonialism, deportation, dislocation, and multiple migrations. But now in Canada, I am also a marginalized, black, Muslim woman.

Growing up in Ethiopia in the region now known as Killil Five, my life was filled with trauma as I watched my pastoralist family lose its herds. This trauma was extended when Mohamed Siad Barrie came to power in 1969 and invaded Eastern Ethiopia (Killil Five) with dire consequences for the population. Those challenges increased when the military regime in Ethiopia started a systematic ethnic cleansing campaign against ethnic Somalis in Ethiopia, putting my family and I at risk again. Before these events began to unfold, my mother managed to educate me, making me one of a handful of Somali girls who got the chance for education. A credit to my mother, while other Somali girls in that region never managed to pass beyond elementary school I was the only one who continued through higher education and professional working life. As a result, during the 1977-78 Ethiopian-Somali War, I was the only professional Somali woman working as a journalist in Ethiopia.

The Mohamed Siad Barrie's invasion of Ethiopia in the late 1970s not only endangered ethnic 
Somalis from that region like me, it also created the worst humanitarian disaster in the region as people from that region fled to Kenya, Somalia or Djibouti. In the mid-80s, I left Ethiopia with my four children and nothing else for neighboring Djibouti to escape the threat of death, then to Somalia, and finally to Italy. I arrived in Canada from Italy in the late 1980s through a government refugee resettlement program. Arriving in Canada as a mother with four small children was not easy. The evening of our arrival members of the church that co-sponsored us with the government brought us to a small town in Ontario that we had never heard. On paper our destination showed another city, which I later found out was the address of the church's headquarters. The people dropped us off and left us alone that evening. After spending an entire day in the Rome airport, traveling and dealing with the anxiety of yet again entering another new country, my children and I were hungry and tired. Opening the refrigerator of the house we had been delivered to I found one bag of toast bread, one litre of milk and ham for sandwiches. Our sponsors did not even know whether we ate such food or whether it was enough for a woman and four children. The morning after we arrived, all of us walked to the nearest store to purchase food with the few Canadian dollars we had with us. Since I was educated and had no language problem I managed to get a job that same week making pizza at a small pizzeria and earning a minimum wage salary at the time. Since my income was not enough to support the family, I also managed to get a second job at highway truck stop close to where we lived. After gaining a Canadian education at local colleges I finally managed to get jobs with decent salary. Therefore, for the past two decades, with additional education in Canada, I have been working as a service provider in community resettlement programs, community health centers, doing research, teaching at colleges and universities. My community work, research, personal experience of marginalization, labour market barriers, health disparities, and the effects of prolonged trauma have helped me to connect with others with similar experiences.

\section{Lessons I Learned from Resettled Refugees in Canada}

As I mentioned earlier, I started my career working with immigrants and refugees in the employment sector as well as in settlement work for agencies like COSTI Immigrant Services and The Self-Help Resource Centre in Toronto. Yes, I needed to have two or three jobs to support my children as many working newcomers do. While working with immigrants and refugees I realized the service disparities for certain refugees, especially Muslims after 9/11.

This had an impact on my community who arrived in Canada as I did in the late-1980s through humanitarian settlement programs or as refugees directly from refugee camps scattered throughout Africa, the Middle East and Europe. Through my work, I came to understand how early interventions with extended support systems, including availability of clinical intervention, and other resettlement services, such as learning the language and culture, are important for refugees. Refugees come to this country after having lived in camps for extended periods of time. For refugee children who are either were born in camps or grew up there their resettlement experience is a struggle. Upon arrival in the resettlement countries such as Canada all children are enrolled in educational programs without first exploring their level of education or their initial needs. This experience re-traumatizes refugee children as seen by Somali-Canadian students increasing their dropout rates and mental health issues. For 
the past two decades these issues has seen in Somali-Canadian students and during the community meetings at The Somali Task Force established by the Toronto District School Board in the 2013-2014. Somali students are part of other refugee communities where their children upon arrival are assigned to classes based on their age but not necessarily on their knowledge (Abdi, 2012). Adults who are struggling to resettle their families miss out on the limited resettlement services such as language learning programs, while their past educational levels are not acknowledged. These educational tensions help put refugees on a track of prolonged poverty. In my case, I came to this county as an educated woman with a postsecondary degree, but because it was not recognized I was forced to restart my education without receiving any credit for my past education. Having to re-educate myself not only added a financial burden, which I will be paying off for the rest of my life, but it also meant I was only able to join the work force later on in my life. It is a delay that will affect me when I retire, keeping me in a life of poverty as a senior citizen. I now understand how my early working years in Canada earning minimum wages and in-between interruption to get an education will affect my later life (Siltanen, 2007; Johnson, 2012).

As a refugee, crossing borders and changing citizenship create their own stresses that are affecting their health and their emotional wellbeing (Agar, 1999; Papadopoulos, 2002, 2006). In my work, I have encountered refugees who are overwhelmed by these stressor and the multiple barriers they encounter during resettlement including ethnic, religious and racial discrimination keeping them within silent systems of "economic apartheid" (Chundamala et al., 2006; Meadows et al., 2001; Teelucksingh \& Galabuzi, 2005). A Somali client from a community health centre where I worked described her personal experience of resettlement:

When I arrived, I was so busy in taking care of my three children who were under five years old. When they became school age and I started thinking about other resettlement needs such as learning the language to secure employment, I found myself not qualifying for most of the language programs. Feeling useless and depressed, all my nightmares [about the war] also got stronger. I am now having a hard time taking care of myself and my family (Personal conversation with a client at Women's Health in Women's Hands Community Health Centre, January 2009).

Somali-Canadian women, most of whom are single mothers whose husbands were lost in the war, struggle with being the head their households. They also have to deal with flashbacks of their refugee/war experiences and post traumatic stress disorder (PTSD). Being in a country where they do not speak the language and sometimes have to deal with unfamiliar cultural and social landscapes, the women's stress increase and persist. The families I worked with when they arrived resettled in lower-income, crime-ridden and racialized neighbourhoods due to an absence of affordable housing, lack of language skills or basic education and a decade later still live there. The experiences are the same for those who had skills, due to barriers I mentioned earlier and described by Danso (2002) and (Williams et al., 2003).

The neighbourhoods where most of Toronto's Somalis live-James Town and Lawrence Heights - are the most socio-economically disadvantaged communities in Toronto and have been designated as "priority neighbourhoods" by the City of Toronto. After having lived in 
Toronto for more than two decades, many Somalis still reside in these neighbourhoods and continue to experience disproportionate levels of poverty, violence, homelessness, inadequate housing, racial and religious discrimination, especially following 9/11 (Aw-Osman, 2008; author's own, 2009, 2012;; Somali Youth Conference, 2010). To complicate matters, many of these single mothers are also survivors affected by their previous ordeals and the strains of relocation (Danso, 2002). While there is abundant research about immigrants and their integration, there is an absence of literature documenting refugee experiences of women survivors of wars in Canada, like Somali women.

\section{My Research Interest in Resettled Refugees and Somali-Canadians as a Case Study}

My motivation for doing a study based on Somali-Canadian women's experiences comes from my own personal history, the stories I have heard from Somali women over the course of my past researches and Somalis I came in contact with while working for community health clinics.

I noticed over the years and during my current research how women who are head of households in Somali-Canadian communities struggle with past traumatic experiences that remain buried until they are triggered by their new experiences such as racism and exclusionism based sometimes on geopolitical preference. The troubling aspect is that these feelings or "the old present" as Margaret Wilkinson calls it (2010, p. 4), can be transmitted from one generation to another via mirror neurons (Cozolino, 2010; Farmer, 2009; Nunn et al., 2008). Some say the presence of intergenerational trauma transference can have an impact on the lives and future of Somali-Canadian youth.

To understand these patterns of trauma within the Canadian Somali community, I read other Somali Diaspora studies such as Schwerdtfege and Goff (2007) and Robertson et al. (2006) who conducted their research in UK and the US Somali communities to help me understand and explain how trauma, migration and past ordeals are transposed from one generation to the next. Furthermore, in my own study I linked cutting-edge neurobiological analysis of trauma and healing methods including the process of Neuroplasticity. Studies by Cozolino (2010), Siegel $(2007,2011)$ and van der Kolk (2014) helped me understand these processes and explain the ways that environmental stressors affects survivors of wars, creating an intergenerational trauma that is relived through children's struggles.

The intergenerational affects of trauma is a community concern and a topic of conversation as we always find ourselves discussing these issues and their impacts on the second generation. In recent years the adjustment issues of Somali youth have been covered in the Canadian media and been the subject of Somali-Canadian community reports. An estimated $70 \%$ of Canadian-Somali youth exhibit the effects of trauma, resulting in behavioural problems, addictions, gang membership, and even participation in extremist religious groups that build on youth vulnerability and impressionability as a recruitment strategy (Aw-Osman, 2008; Canadian Press, 2010; Jibril, 2011; Aulakh, 2010; York Community Services, 1999). Early Somali resettlement literature such as Michael Ornstein's 2006 report showed that 33\% of Somali youth between 25 and 34 dropout of high school. Others link this high dropout rate with language difficulties (Brown, 2006), or early trauma experiences (Bhui YCS, 1999) and 
existing disparities within the educational system (Die et al., 1997).

The dropout rate is a pressing concern for Somali mothers interviewed for my study. They view higher education as the necessary step for getting out of poverty, integration into the labour market, and opening the doors for better life as well as job opportunities for their children. Over the years attending community meetings in Toronto and having individual conversations with mothers and community leaders, I have observed that Somali parents blame both individual and systemic factors for making their children more vulnerable to the justice system, dangerous gang activities, or religious extremists. The situation within Somali communities across Canada is so bad that some parents take drastic measures, such as sending their children to other countries deemed safer. Other parents enrol their children in religious studies, unfortunately making them more vulnerable to Islamic extremists.

Recently, Somali mothers have begun reporting higher numbers of youth involved in the justice system or dying in the streets of Canadian cities. One instance that made the headlines is the unsolved deaths of 35 Somali youth killed in Edmonton, Calgary and Fort McMurray since 2006 (Siad, 2011). Since December 2010, Canadian media such as CBC's "The Fifth Estate" and the Toronto Star have also reported on Somali youth who relocate from Ontario to work in the oil industry in Alberta. These mostly young men are confronted with the same systemic barriers there too. Losing hope some of them make the deadly choice of participating in the drug trade while others have been killed by association or mistaken identify (Jibril, 2011, p. 19).

In late October 2008, I was invited to facilitate a stress reduction and better living workshop at a community center in the west of Toronto. The women shared their thoughts about poverty, housing issues, neighbourhood crime, lack of services, and the problems facing their children. During the discussion, one woman talked about her own fear in relation to police profiling, and how she and her son were afraid when they heard a knock on their door, especially in the evening. I had noticed this woman when I first entered the room; she was sitting in the corner and seemed sad and isolated. When I asked the women what the most stressful situation in her life was, she spoke up:

I am unable to escape violence. A lot of things happened to me while in the [refugee] camp, and when I came to Canada I thought I left all the violence behind. From time to time, I hear gun fire and [learn about] dead young men in my neighbourhood. Last week, the police came to my house in the middle of the night knocking the door really hard, looking for my son, which scared me. I felt I was back in Mogadishu. The following summer, in mid-July 2009, her 16-year-old son was killed in a knife fight with neighbourhood kids.

In order to understand violence and trauma in Somali-Canadian communities, I draw from a wide range of literature and utilize a strong historical background and theoretical approach, both of which shed light on the impact of past and present factors that function as triggers for Somalis who lived through war. This further isolates those who are traumatized making integrating into new communities much more difficult.

The intersectionality of race, religion, migration status and geopolitics makes a difference in 
immigration, resettlement and integration for those who have been rescued from unimaginable circumstances. Those of us who are interested in this issue should not generalize about non-European newcomers but, rather, identify refugee needs based on the refugee's experience of trauma and the number of years they have been displaced without access to education or health care. The history of Muslim refugee resettlement based on the Somali case study that I just completed show us that the issue of recognition and belonging is one of the major challenges for refugees. We need to look at how resettlement countries such as Canada provide newcomers with a sense of identity.

The Center for Forced Migration Studies/Buffett Institute for Global Studies (CFMS) held a workshop in December 2015 that was organized to allow experts to share their knowledge about refugee resettlement and integration. What, I asked the small breakaway group I was working with was, have we learned from past resettlement experiences when the refugees were from non-European and non-Christian countries? Why aren't we talking about the real issues like silent eugenics in immigration and integration? I believe there can be a social integration aspect of community development that fosters belonging and a sense of acceptance or integration for communities like Somalis or the Syrians who are now beginning to arrive.

In the past few years, global political, economic and geopolitical forces have brought social changes that are now determining these silent eugenics and the level of belonging based on geopolitically based inclusion systems. These changes ease the process of integration for some non-European newcomer communities while they continue to exacerbate the poverty of other non-European refugees and immigrants, silently imposing geopolitical based selection criteria that marginalize, oppress and exploit them.

\section{Chosen Method for My Research}

While searching for an appropriate method to use for my $\mathrm{PhD}$ study (collecting stories of female survivors of a prolonged war), I recalled a quotation by Paolo Freire (1970) in a book written by Chin and Rudelius-Palmer (2010): "Storytelling in a human rights context allows those who have been marginalized to tell their stories in an 'authentic and meaningful dialogue and [with] reflection that identifies causes"” (p. 268). This is exactly what I wanted to do by documenting the stories of Somali-Canadian women who continue to live in a condition that looks like permanent refugee camps in Canadian neighbourhoods. With this in mind, I interviewed twelve women/mothers who were born in different regions of the Horn of Africa where Somalis reside. Using their stories, I explored the emotional patterns each woman experienced and how both her environment and community created stresses affecting the quality of her life and her children. Doing life history research opened a window for me as a new researcher to explore, not only current issues, but also the historical contexts of trauma within a certain period of each woman's life, in this case her forced migration and resettlement experiences. This method allowed me to analyze not only personal experiences but also their interaction with current services that are available to them and their attitudes and behaviours (decision making and adaptation processes) that may have been influenced by the community's past and present experiences. After completing my study I realized how 


\section{Ml Macrothink}

important my methodological choice was to my study. As a feminist researcher, I also turned to scholars Sandra Harding (1991) and Patricia Hill Collins (2000). I came to understand from these feminist's work that women's stories allow researchers like me who are part of the community and studying the thick and enriched description of data that addresses the epistemological and ontological question of their "self-defined viewpoints". The individual stories of my participants not only gave me a deeper understanding of existing issues, but a window onto the silencing powers of culture/religion and external systems that marginalize the women in my community. The process of storytelling also brought out the still hidden silence of gender-based violence and shame regarding their children's lack of integration. It raised questions about the kind of intervention or listening method we need to use in social work practice/intervention when working with communities like this.

Based on the stories told by the participants of my study, I explored the link between past and present trauma and healing practices that are promising. These practices based on culture, social neuroscience and social work intervention is what I will be using in a format I developed for individual and community intervention. It is a format that came out of a combined knowledge that enabled me to discuss issues without further stigmatizing the women, providing educational sources and healing practices. This will help Somali-Canadians who are divided by past trauma and have lost their extended cultural social support systems making them isolated and underserved. Coming from anti-oppression social work practice, I see the need for resettlement programs that include clinical intervention when emotional issues warrant it along with services that attend to the initial needs of resettlement such as housing, food and health care. From a practice perspective, service provision needs to start with a flexibility that embraces differences in race, religion, and status of migration. As a survivor of war and someone with refugee life experience and still struggling with resettlement, I see the importance of accommodating the needs of the refugee first, by taking into account their history of forced migration and experiences of resettlement. This type of intervention will require service providers to be open to acquiring new knowledge and collaborating in ways that do not impose their views but encourages choice for the users in the services available to them. This flexible service model, along with my professional social work values of empathy, understanding, social justice and advocating for equality, has helped me think beyond what is currently available in social work practice based intervention.

I have recently participated in short workshops and conferences about Syrian refugees here in Canada and United States that have reminded me how existing resettlement and integration issues of past refugees are being ignored. The old resettlement model based on our moral compass of helping those in need and fulfilling our humanitarian obligation in doing the greater good for the other is being discussed in great detail. I have come to realize, however, that as we are preparing for new arrivals, we are silently implementing an old system. Unless things change in global and local political discourses that determine economic inclusion, things will be the same for those currently arriving in Canada. They will be caught in these systems of exclusion as the other or as terrorist cells in the making and will not be a part of us. 


\section{Conclusion}

We have seen the difference in the economic, social and political integration between people coming from certain geographical locations while others labelled by a continent, a race or a religion are kept on the margins. Canada still denies that such discrimination exists, and instead, touts the Canadian "cultural mosaic" argument in which non-European and non-Christian Canadians have an equal chance of integration. Here I use my own professional history - the number of years I have held multiple jobs to make ends meet while raising my four children - as an example. The silent marginalization of certain refugees and immigrants is not due to a lack of hard work on their part, education or experience but because of implicitly determined qualifications that exclude people based on race, religion and geopolitics. The question is, will Syrians have a better chance to resettle and integrate into Canadian life than Somalis have had?

\section{Acknowledgement}

My dissertation research is funded by The Hilary Weston Foundation.

\section{References}

Andrzejewski, B. W., \& Lewis, I. M. (1964). Somali Poetry: An Introduction. The Oxford Library of African Literature. Oxford University Press, UK.

Abdi, F. (2012). Kicked out of school: The perspectives of Somali students on why they have not completed high school (Order No. MR90060). Available from Dissertations \& Theses @ York University; ProQuest Dissertations \& Theses Global. (1221266628). Retrieved from http://ezproxy.library.yorku.ca/login?url=http://search.proquest.com/docview/1221266628?ac countid $=15182$

Aulakh, R. (2010, March 22). Somali-Canadians caught in Alberta's deadly drug trade. The Toronto Star, Retrieved from http://www.thestar.com/news/investigations/2010/03/22/somalicanadians_caught_in_albertas _deadly_drug_trade.html

Aw-Osman, F. (2008). Somali youth: Stop the violence. Retrieved from http://wardheernews.com/Articles_08/December/18_somali_youth_farah.html

Ager, A. (Ed.). (1999). Refugee perspectives on the experience of forced migration. London, UK: Pinter.

Brown, L. (2006). Dropout, failure rates linked to language. The Toronto Star. Retrieved from http://www.yorku.ca/goldring/clippings/dropout_rates_link_language.pdf

Bhui, K., Craig, T., Mohamud, S., Warfa, N., Stansfeld, S. A., Thornicroft, G, ... McCrone, P. (2006). Mental Disorders among Somali refugees: Developing culturally appropriate measures and assessing socio-cultural risk factors. Social Psychiatry and Psychiatric Epidemiology, 41, 400-408. http://dx.doi.org/10.1007/s00127-006-0043-5

Bokore, N. (2009). Female survivors of African wars dealing with the past and present. 
Journal of Sociological Research, 1(1), E5. http://dx.doi.org/10.5296/jsr.v1i1.189

Bokore, N. (2012). Suffering in silence: A Canadian-Somali case study. Journal of Social Work Practice: Psychotherapeutic Approaches in Health, Welfare and the Community.

Bulhan, H. A. (2008). Politics of Cain: One hundred years of crises in Somali politics and society, Bethesda, MD: Tayosan International Publishing.

Buchheim, A., Labek, K., Wlater, S., \& Viviani, R. (2013). A clinical Case Study Of A Psychoanalytic Psychotherapy Monitored With Functional Neuroimaging. Frontiers in Human Neuroswcience, 7.

Burton, R. F. (2007). First Footsteps into East Africa; or, an Exploration of Harar. Fairford, UK:Echo Library.

Cassanelli, L. (1982). The Shaping of Somali Society: Reconstructing the history of a pastoral people, 1600-1900. Philadelphia, PA: University of Pennsylvania Press.

Cassanelli, L. (2011). The partition of knowledge in Somali studies: Reflections on Somalia's fragmented intellectual heritage, Bildhaan: An International Journal of Somali Studies, 9.

Collins, P. H. (2000). Black Feminist Thought: Knowledge, consciousness, and the politics of empowerment. New York, NY \& London, UK: Routledge.

Cozalino, L. (2010). The Neuroscience of psychotherapy: Healing the social brain. New York, NY: W.W. Norton and Company, Inc.

Chin, K., \& Rudelius-Palmer, K. (2010). Storytelling As A Relational And Instrumental Tool For Addressing Racial Justice, Race/Ethnicity. Multidisciplinary Global Context, 3(2), 265-281.

Dei, G. S., Mazzuca, J., McIsaac, E., \& Zine, J. (1997). Reconstructing drop-out': A critical ethnography of the dynamics of black student's disengagement from school. Toronto, ON: University of Toronto Press.

Eugenics Research Association. (1920). Minutes of Meeting of Committee on Immigration of the Eugenics Research Association, held at the Harvard Club, New York City, at 11 A.M., $\begin{array}{llll}\text { February } 25, & 1920 . & \text { Retrieved }\end{array}$ https://cla.umn.edu/sites/cla.umn.edu/files/minutes_of_meeting_1920.pdf

Farmer, R. (2009). Neuroscience and social work practice. Thousand Oaks, CA: SAGE Publications.

Folson, R. B. (2004). Calculated kindness: Global restructuring, immigration and settlement in Canada. Halifax, NS: Fernwood Publishing.

Galabuzi, G. E. (2001). Canada's creeping economic apartheid: The economic segregation and social, marginalisation of racialised groups. CSJ Foundation for research education, 3-129.

Galabuzi, G. (2002). Social Exclusion. Proceedings from The Social Determinants of Health 
Across the Life-Span Conference, Toronto. Retrieved from http://www.phac-aspc.gc.ca/ph-sp/oi-ar/03_inclusion-eng.php

Galabuzi, G. E. (November, 2005). The Racialization of Poverty in Canada: Implications for Section 15 Charter protection. The National Anti-Racism Council of Canada National Conference Ottawa.

Galabuzi, G. E. (2006). Canada's Economic Apartheid. Toronto: Canadian Scholars' Press. Books Group.

Hyndman, J. (2011). Research Summary On Resettled Refugee Integration In Canada. Retrieved from http://celarc.ca.ezproxy.library.yorku.ca/cppc/231/231466.pdf

Harding, S. (1991). Whose Science? Whose Knowledge? Thinking from Women's Lives. Cornell University Press, Ithaca, New York.

Jibril, S. (2011). Cashberta: Migration experiences of Somali-Canadian second generation youth in Canada. Master of Environmental Studies (MES) Major Paper, 17(1).

Johnson, K. (2012). Access for All? Struggles Over Citizenship and Social Policy. Canadian Women's Studies/Les Cahiers de la Femme, 29(3), 124-137.

Matto, H. C., Strolin-Gltzman, \& Ballan, M. S. (2014). Neuroscience for Social Work: Current Research and Practice, Springer Publishing Company, New York.

Mullaly, B. (2002). Challenging oppression: A critical social work approach (1st ed.). Toronto, ON: Oxford University Press.

Mullaly, B. (1997). Structural Social Work: Ideology, Theory and Practice (2nd ed.). Toronto, ON: Oxford University Press.

Nunn, K., Hanstock, T., \& Lask, B. (2008). Who's who of the brain: A guide to its inhabitants, where they live and what they do. London, UK \& Philadelphia, PA: Jessica Kingsley Publisher

Robertson, C. L., Halcon, L., Savik, K., Johnson, D., Spring, M., Butcher, J., ... Jaranson, J. (2006). Somali and Oromo refugee women: Trauma and associated factors. Journal of Advanced Nursing, 56(6), 577-587. http://dx.doi.org/10.1111/j.1365-2648.2006.04057.x

Samatar, A. I. (Ed). (1994). The Somali Challenge: From catastrophe to renewal. London, UK: Lynne Riennner Publishers Boulder.

Samatar, S. S. (1982). Oral poetry and Somali nationalism: The case of Sayid Mohammad Abdulle Hassan. New York, NY: Cambridge University Press.http://dx.doi.org/10.1017/CBO9780511735370

Samatar, S. S. (1991). Somalia: A nation in turmoil. London, UK: Minority Rights Group.

Schwerdtfege, K. L., \& Goff, B. S. (2007). Intergenerational transmission of trauma: Exploring mother-infant prenatal attachment. Journal of Traumatic Stress, 20(1), 39-51. http://dx.doi.org/10.1002/jts.20179 


\section{Macrothink}

International Journal of Social Work

ISSN 2332-7278 2016, Vol. 3, No. 1

Siad, A. (2011, June 06). Local mothers join together: Somali women's group seek changes in community after deaths of 35 young men in Alberta over the past five years. The Calgary Journal.

Siltanen, J. (2007). Social Citizenship and the Transformation of Paid Work: Reflections on Possibilities for Progressive Change, in Vivian Shalla and Wallace Clement, eds., Work in Tumultuous Times: Critical Perspectives, Montreal and Kingston: McGill-Queen's U. Press.

Siegel, D. (2007). The mindful brain: Reflection and attunement in the cultivation of well-being. New York, NY: W.W. Norton \& Company.

Siegel, D. (2011). Mindsight: The new science of personal transformation. New York, NY: Bantom Books

The Canadian Press. (2010, March 18). Canadian Somalis fear militant group targeting youths.

van der Kolk, B. A. (2014). The Body keeps the score: Brain, mind, and body in the healingof trauma. New York, NY: The Penguin Group.

Wilkinson, M. (2010). Changing minds in therapy: Emotion, attachment, trauma, and neurobiology. New York, NY: W.W Norton \& Company.

\section{Notes}

Note 1. Integration restrictions rooted in systemic barriers based on race and religion are discussed by researcher such as Edward Grace Galabuzi (2001, 2005 \& 2006).

\section{Copyright Disclaimer}

Copyright reserved by the author(s).

This article is an open-access article distributed under the terms and conditions of the Creative Commons Attribution license (http://creativecommons.org/licenses/by/3.0/). 